\title{
FENOMENA PEDAGANG KAKI LIMA \\ DALAM SUDUT PANDANG KAJIAN FILSAFAT HUKUM \\ DAN PERLINDUNGAN KONSUMEN
}

\author{
Shidarta \\ Business Law Department, Faculty of Humanities, BINUS University \\ Jln. Kemanggisan Ilir III No. 45, Kemanggisan - Palmerah, Jakarta 11480 \\ shidarta@binus.edu
}

\begin{abstract}
Street vending always becomes one of main problems in many big cities like Jakarta if the existence of street vendors is perceived as a burden and never comprehensively addressed. It is the main concern raised in this article. A more comprehensive perspective can be applied by using philosophical and legal approaches. This article provides two points of view in term of the phenomena, i.e. legal philosophy and consumer [legal] protection. The first relates the subject matter to the universal legal values known as the legal objectives. The second one includes two perspectives, i.e. the proctection for consumers of street vendor's products and that for street vendor as consumer of [legal] public policy.
\end{abstract}

Keywords: street vendor, legal philosophy, consumer protection

\begin{abstract}
ABSTRAK
Pedagang kaki lima akan senantiasa menjadi persoalan besar bagi kota besar seperti Jakarta apabila keberadaannya hanya dilihat sebagai beban dan tidak komprehensif. Perspektif yang lebih komprehensif dapat dilakukan dengan memakai pendekatan filsafat dan hukum. Hal ini merupakan isu utama yang diangkat dalam tulisan. Terhadap hal itu, ditawarkan dua sudut pandang, yaitu fenomena pedagang kaki lima dari kaca mata filsafat dan perlindungan konsumen. Sudut pandang pertama mengaitkan pada nilai-nilai universal yang menjadi tujuan hukum. Lalu, sudut pandang kedua, perlindungan konsumen mencakup dua sisi, yaitu perlindungan terhadap masyarakat yang memanfaatkan produk pedagang kaki lima dan perlidungan konsumen terhadap pedagang kaki lima sebagai konsumen kebijakan publik.
\end{abstract}

Kata kunci: pedagang kaki lima, filsafat hukum, perlindungan konsumen 


\section{PENDAHULUAN}

Ada satu pertanyaan menarik yang tidak mudah untuk dijawab, yakni tentang hal apa yang secara esensial membedakan persepsi antara (1) pembentuk undang-undang, (2) aparat penegak hukum, dan (3) para pedagang kaki lima (selanjutnya disingkat PKL) tatkala mereka semua melihat fenomena PKL di kota Jakarta ini. Pertanyaan ini yang ingin dikaji lebih jauh dalam ulasan bagian pertama tulisan ini. Ulasan ini menggunakan pendekatan filsafat hukum, suatu pendekatan yang mungkin tidak lazim dalam wacana tentang PKL.

Kehadiran PKL di tengah-tengah masyarakat kerap menimbulkan pro dan kontra. PKL sebagai pelaku usaha sering diberi label sebagai pedagang yang memiliki tanggung jawab rendah atas kualitas barang/jasa yang ditawarkan kepada konsumen. Bagian kedua dari tulisan ini memperlihatkan perspektif konsumen dalam melihat PKL.

Pada bagian ketiga ditampilkan suatu sudut pandang lain bahwa PKL sebenarnya adalah "konsumen" juga, yakni konsumen suatu kebijakan pemerintah. Kebijakan ini sangat mungkin tidak cukup berpihak kepada mereka, sehingga PKL akhirnya tumbuh sebagai respons sosial dari kenyataan yang mereka hadapi sehari-hari.

Ketiga bagian tersebut secara bersama-sama ingin menghadirkan suatu kerangka berpikir yang lebih fundamental tentang PKL. Dengan demikian, hakikat dari eksistensi PKL ini dapat dipahami dari berbagai sudut pandang, yang pada gilirannya akan membawa kita kepada pendekatan yang lebih bijaksana dan dapat mengantarkan kita kepada suatu metode penyelesaian masalah yang lebih komprehensif (dalam hal ini terkait masalah pembinaan dan perizinan).

\section{METODE}

Tulisan ini merupakan hasil elaborasi naskah seminar yang pernah disajikan beberapa tahun lalu di hadapan pejabat terkait Pemda Provinsi Jakarta (Shidarta, 2006) namun belum dipublikasikan. Elaborasi dilakukan dengan melakukan penelitian terhadap perkembangan beberapa tahun terakhir, khususnya setelah ketentuan baru berupa Peraturan Gubernur Provinsi Daerah Khusus Ibukota Jakarta Nomor 33 Tahun 2010 tentang Pengaturan Tempat dan Pembinaan Usaha Mikro Pedagang Kaki Lima di Provinsi Daerah Khusus Ibukota Jakarta, diberlakukan.

Penelitian menggunakan metode yang lazim digunakan dalam penelitian filsafat dan penelitian hukum. Metode yang dimaksud disebut analisis-sintesis. Di dalam metode analisis, fenomena PKL dipilah ke dalam konsep-konsep yang menopangnya dan diberikan penelaahan, untuk selanjutnya dilakukan metode sintesis agar dapat dilakukan penggabungan pemahaman (Sudarto, 1996:59-60). Dengan cara ini diharapkan dapat diperoleh pengertian yang baru tentang fenomena PKL ini.

\section{HASIL DAN PEMBAHASAN}

Berangkat dari dua perspektif yang digunakan dalam tulisan ini, maka dapat disajikan pembahasan menjadi tiga subtopik. Pertama, PKL ditinjau dari perspektif filosofis. Kedua PKL ditinjau dari perspektif perlindungan konsumen, yang masing-masing akan muncul dalam subtopik kedua dan ketiga. 


\section{PKL dalam Perspektif Filosofis}

Fenomena PKL adalah suatu fenomena sosial. Secara umum terdapat sejumlah ciri yang dapat dilekatkan pada PKL, sekalipun di beberapa tempat ciri-ciri ini mungkin tidak berlaku. Ciri-ciri yang dimaksud adalah berusaha di lokasi yang tidak sesuai dengan peruntukannya; tidak dibekali izin usaha yang resmi dari instansi berwenang; memiliki mobilitas tinggi (mudah berpindah-pindah mengikuti akumulasi konsumen); melayani langsung konsumen akhir; tingkat kedisiplinan terhadap hukum rendah; cenderung sangat pragmatis dalam memandang hukum.

Ciri pertama tampaknya merupakan ciri yang paling dominan untuk menetapkan karakter PKL. Pasal 1 butir 13 Peraturan Gubernur Provinsi Daerah Khusus Ibukota Jakarta Nomor 33 Tahun 2010 mendefinisikan PKL sebagai "kegiatan usaha jasa perdagangan yang menempati prasarana kota, fasilitas sosial dan fasilitas umum milik Pemerintah Daerah, tanah/lahan milik perorangan/badan yang telah mendapat izin dari Gubernur.” Definisi ini kurang lebih masih seirama dengan aturan lama yang pernah dimuat dalam Peraturan Daerah Nomor 5 Tahun 1978 tentang Pengaturan Tempat dan Usaha serta Pembinaan Pedagang Kaki Lima dalam Wilayah Daerah Khusus Ibukota Jakarta, yang memaknai PKL sebagai “...mereka yang di dalam usahanya mempergunakan bagian jalan/trotoar dan tempat-tempat untuk kepentingan umum yang bukan diperuntukkan tempat usaha serta tempat lain yang bukan miliknya" (cetak tebal dan garis bawah oleh penulis-red). Definisi ini mengandung konsekuensi pemikiran sebagai berikut: (a) PKL berusaha di tempat-tempat yang diperuntukkan bagi kepentingan umum; (b) tempat-tempat tersebut bukan untuk kegiatan usaha; (c) tempat-tempat tersebut tidak dimilikinya.

Sementara itu, ciri kedua tidak selamanya dapat dilekatkan pada PKL. Logikanya, memang setiap PKL yang berusaha di tempat-tempat menurut kriteria tidak boleh diberikan izin oleh pemerintah. Jika pemerintah tetap memberikan izin untuk kategori PKL demikian, secara definitif ada suatu kontradiksi peristilahan (contradictio in terminis) serta terjadi inkonsistensi di dalam kebijakan pemerintah. Namun rupanya peraturan memiliki logika berpikir tersendiri. Kendati tempat usaha PKL tidak sesuai dengan peruntukannya, dalam kenyataannya tetap ada usaha PKL yang diberikan izin. Dengan demikian, ada kriteria PKL yang legal (karena diberikan izin berusaha di tempat yang sesungguhnya tidak sesuai dengan peruntukannya) dan PKL yang ilegal (karena tidak berizin).

Tempat berusaha yang boleh ditempati oleh PKL adalah tempat-tempat yang ditunjuk atau ditetapkan oleh Gubernur, meliputi tempat yang dikuasai oleh pemerintah maupun swasta. Di luar tempat-tempat yang telah ditunjuk/ditetapkan ini, tidak ada izin untuk PKL. Mereka yang berusaha di tempat-tempat tersebut harus terdaftar. Tempat usaha mereka tidak boleh berupa bangunan permanen (misalnya cukup berupa tenda dan tidak boleh dijadikan tempat tinggal). Izin yang sudah diberikan tidak boleh dipindahtangankan dalam bentuk apapun juga.

PKL yang tidak berusaha di tempat yang ditunjuk/ditetapkan, diancam dengan sanksi pidana. Sanksi juga dikenakan bagi mereka yang berusaha di tempat yang diperbolehkan, tetapi tidak terdaftar dan tak berizin. Sementara itu, untuk tempat-tempat yang sudah ditunjuk/ditetapkan, namun kemudian disalahgunakan (misalnya didirikan bangunan permanen), maka Gubernur dapat mencabut izin penggunaan tempat usaha tersebut.

Suatu penelitian yang dilakukan oleh Badan Pusat Statistik DKI Jakarta dari waktu ke waktu memperlihatkan bahwa lokasi yang paling banyak ditempati PKL adalah trotoar dan badan jalan. Tempat lain adalah halaman pasar/pertokoan, lahan parkir dan halte, jalur hijau dan taman kota, lahan kosong, dan halaman terminal/stasiun (bandingkan dengan Bromley, 2000: 1-28).

Trotoar dan badan jalan memang lokasi favorit PKL. Lokasi ini dipilih karena mereka ingin sedekat mungkin "menjemput bola", yakni mencegat konsumen yang membutuhkan layanan PKL. 
Oleh karena lokasi-lokasi tersebut tidak didesain sebagai tempat jual-beli, maka izin penggunaan tempat-tempat tersebut diberikan secara terbatas. Para pelaku usaha kecil sekelas PKL ini tentu menyadari hal tersebut. Itulah sebabnya, sistem usaha mereka dijalankan dengan mobilitas tinggi. Mereka, misalnya, menggunakan gerobak yang mudah berpindah atau tenda yang gampang dibongkar-pasang.

Fakta menunjukkan bahwa lokasi yang ditunjuk/ditetapkan secara resmi oleh pemerintah daerah untuk para PKL ini jumlahnya sangat terbatas dibandingkan dengan jumlah PKL yang ada dan terus membanjiri ibukota Jakarta. Akibatnya, sebagian besar PKL memilih berusaha di tempat-tempat yang tidak berizin.

Sekalipun di lokasi tak berizin tersebut telah dipasang rambu-rambu larangan berdagang atau kerap dilakukan razia oleh aparat pemerintah daerah, tetap saja PKL hadir di sana. Tingkat kedisiplinan mereka terhadap hukum terkalahkan oleh sikap pragmatis mereka dalam memandang hukum. Rambu-rambu, pengumuman, razia penertiban, atau apapun larangan yang disampaikan, tidak ada artinya karena semua itu bertolak belakang dengan prinsip kemanfaatan langsung yang dikejar. Ulasan dari perspektif filosofis dapat dimulai dari prinsip kemanfaatan ini.

Nilai kemanfaatan (utilitas) merupakan kata kunci tentang persepsi para PKL ini dalam melihat hukum. Nilai kemanfaatan adalah suatu nilai yang hadir secara konkret, kasuistik, dan partikular. Fenomena PKL akan selalu ada di lokasi-lokasi sepanjang di tempat itu mereka mendapatkan kemanfaatan demikian. Apa yang dipandang bermanfaat oleh PKL ini adalah apa yang dilihat dari sudut pandang masing-masing secara kasuistik dan untuk suatu tindakan itu sendiri saja. Nilai kemanfaatan itu direfleksikan secara sempit sebagai keuntungan pribadi atau sekelompok kecil di antara mereka. Mereka tidak pernah mengaitkan keuntungan itu dengan "kemanfaatan" secara umum, apalagi kemanfaatan untuk hal-hal yang bersifat estetis seperti kebersihan dan keindahan kota. Cara pandang demikian dapat disebut sebagai cara pandang yang partikular.

Tentu saja tidak cukup adil untuk memandang fenomena PKL dan cara pandang partikular ini sebagai suatu "kesalahan" yang harus ditimpakan sepenuhnya kepada masyarakat PKL tersebut. Cukup banyak penelitian yang menunjukkan bahwa PKL merupakan komunitas yang swakarya, yaitu bekerja secara mandiri (wiraswasta), ulet, dan sangat efisien. Mereka juga orang-orang yang tidak sepenuhnya "buta hukum" atau "buta politik" (lihat misalnya Murray, 1994; dan Simanjuntak, 2007).

Namun nilai keadilan sendiri dalam perspektif filosofis menempati ruang yang secara konvensional dipersepsikan berdimensi universal. Artinya, adil dan tidak adil tidak bisa dikaji dengan melihat sudut pandang PKL itu semata. Tindakan mengambil hak pejalan kaki untuk berjalan dengan aman dan nyaman di trotoar atau tindakan mengambil sebagian badan jalan sehingga menghambat arus laju kendaraan, boleh pula ditengarai sebagai perilaku tidak adil. Tindakan itu disebut "tidak adil" karena ada hak orang lain yang sudah terampas. Dengan demikian adil dan tidak adil adalah persoalan memperbandingkan antara hak seseorang dengan hak pihak-pihak lain secara interaktif.

Kecenderungan menggunakan perspektif nilai keadilan seperti ini jelas bukan tipikal yang dapat dilekatkan kepada kelompok PKL. Wacana tentang keadilan adalah wacana dari kalangan yang justru tidak terlibat langsung dengan kehadiran PKL. Dalam bahasa filsafat, mereka dikatakan sebagai orang-orang yang melakukan distansi (mengambil jarak) dari persoalan ini. Proses distansi ini tidak dapat serta merta diartikan sebagai tindakan lari dari persoalan. Proses distansi justru diperlukan agar mereka dapat memperoleh gambaran (picture) secara lebih luas, sekalipun akhirnya menjadi tidak lagi detail. Sudut pandang seperti ini adalah sudut pandang dari para pembentuk undang-undang. Sebagai catatan, dalam tulisan ini istilah "undang-undang" diartikan secara material bukan secara formal.

Dua sudut pandang yang telah dikemukakan, yakni perspektif PKL dan perspektif pembentuk undang-undang, sering kali berbenturan. Di satu sisi, pembentuk undang-undang ingin mengatur PKL 
sesuai dengan kewenangan yang dimilikinya. Aturan itu harus berlaku umum, sehingga kepentingan umum pula yang dijadikan acuan utama, bukan sekadar kepentingan mikro kaum PKL saja. Untuk itu maka nilai keadilan lalu diadopsi ke dalam undang-undang yang dibuat.

Jadi setiap undang-undang sudah harus diasumsikan adil begitu undang-undang itu diberlakukan dan masuk dalam konstelasi norma hukum positif. Ajaran demikian merupakan ciri khas dari Positivisme Hukum.

Idealnya, studi tentang hukum harus dilakukan dalam rangka mendorong tumbuhnya dominasi kesadaran hukum di atas perasaan hukum. Konsep ini sesungguhnya bukan barang baru karena telah disampaikan jauh-jauh hari oleh John Austin dan Jeremy Bentham sebagai pengemuka Teori Kehendak (The Will Theory). Menurut mereka, pada saat pembentuk undang-undang memformulasikan suatu peraturan, ia harus memerhatikan kehendak-kehendak semua komponen, mulai dari penguasa pada saat itu (current sovereign), penguasa sebelumnya (earlier sovereign), penguasa di tingkat bawah (subordinate powerholders), dan pemangku kepentingan lainnya (any other group/individuals). Di sini terlihat bahwa kehendak individu tetap diberi tempat untuk diakomodasi, bahkan tidak boleh ditinggalkan, tetapi berada pada tingkat terbawah. Kehendak-kehendak itu semua menyatu dan mencerminkan satu kesatuan kehendak (unity of wills). Adanya kesatuan kehendak inilah yang menjadi syarat untuk tercapainya kesatuan dalam penegakan (unity of enforcement) (Harris, 1982:25-33; juga Shidarta, 2005:13-15).

Sebagaimana layaknya sebuah asumsi, apa yang dinyatakan oleh Positivisme Hukum tersebut ada kemungkinannya meleset. Kesatuan penerapan yang diasumsikan mengikuti kesatuan kehendak (unity of enforcement entails unity of will) dalam kenyataannya sering tidak berlangsung semulus yang dibayangkan.

Tugas menyatukan kehendak (unity of will) sebenarnya adalah tugas dalam tataran filosofis. Repotnya, dalam sistem ketatanegaraan modern, tugas ini tidak lagi dijalankan oleh para filsuf seperti disarankan oleh filsuf Yunani Kuno, Plato. Tugas mengakomodasi kepentingan dan menyatukannya dalam suatu rumusan filosofis, telah diambil alih oleh para politikus. Mereka sebagian adalah wakilwakil rakyat yang duduk di parlemen, baik di tingkat pusat maupun daerah.

Kaum politikus pada dasarnya adalah kaum penyuara kepentingan. Dalam praktik, artikulasi kepentingan yang mereka suarakan sangat bergantung pada lobi-lobi politik. Makin besar akses suatu kelompok kepentingan terhadap para politikus ini, akan makin besar kemungkinan kepentingan itu terakomodasi ke dalam norma hukum positif yang dihasilkan. Dalam posisi seperti inilah lalu terjadi "bias keadilan" di dalam undang-undang yang dihasilkan.

Titik persoalan mulai terlihat di sini. Undang-undang yang diasumsikan "adil" itu lalu harus diterapkan dengan sepenuh hati oleh aparat penegak hukum di lapangan (untiy of enforcement). Untuk menegakkan aturan ini lalu diadakan operasi penertiban. Intensitas penertiban tadi bervariasi, mulai dari upaya preventif sampai tindakan keras dan frontal.

Dari kaca mata aparat di lapangan, penertiban ini merupakan cerminan tanggung jawab mereka di hadapan hukum. Menurut mereka, aparat penegak hukum harus menerapkan hukum. Hukum di sini adalah undang-undang. Jika undang-undang tidak dijalankan, tidak akan ada kepastian hukum.

Alhasil, terlihat ada tiga nilai yang saling bersitegang, yang masing-masing diperjuangkan oleh pembentuk undang-undang, aparat penegak hukum, dan PKL. Nilai-nilai itu adalah nilai keadilan (dipersepsikan oleh pembentuk undang-undang), nilai kepastian hukum (dipersepsikan oleh aparat penegak hukum), dan nilai kemanfaatan (dipersepsikan oleh PKL). Ketiga nilai ini dapat disebut sebagai tiga serangkai tujuan hukum (Radbruch, 1973:170-179). Dengan demikian, dalam perspektif 
filosofis, keberadaan PKL sesungguhnya dapat dilihat dari tiga sudut pandang (dimensi aksiologis) yang masing-masing mewakili tiga kelompok kepentingan seperti yang telah disebutkan. Efektivitas upaya pembinaan dan pemberian izin terhadap PKL di kota-kota besar seperti Jakarta selayaknya berangkat dari kerangka berpikir ini.

\section{PKL dalam Perspektif Konsumen}

Pada uraian sebelumnya telah disinggung tentang tujuan kemanfaatan yang lebih dititikberatkan oleh PKL dalam memandang keberlakuan suatu norma hukum positif. Sudut pandang demikian sebenarnya tidak hanya diwakilkan oleh para PKL, tetapi sesungguhnya juga oleh para konsumen PKL tersebut.

Konsumen adalah istilah yang berkonotasi beragam. Dengan berlakunya Undang-Undang Nomor 8 Tahun 1999 tentang Perlindungan Konsumen (UUPK), kata kosumen berarti orang yang memakai barang/jasa yang tersedia di masyarakat untuk kepentingan sendiri/keluarga/orang lain/mahluk hidup lain, serta tidak untuk diperdagangkan. Jadi, konsumen di sini adalah konsumen akhir (end consumer). PKL dalam berhubungan dengan masyarakat, jelas tidak dalam posisi sebagai konsumen. PKL justru adalah pelaku usaha yang berhadapan dengan konsumen. Menurut UUPK, pelaku usaha adalah orang perseorangan atau badan usaha, baik berbentuk badan hukum atau bukan badan hukum, yang didirikan dan berkedudukan atau melakukan kegiatan dalam wilayah hukum negara RI, baik sendiri maupun bersama-sama melalui perjanjian menyelenggarakan kegiatan usaha dalam berbagai bidang ekonomi.

PKL adalah pelaku usaha yang secara umum (artinya tidak selalu) melayani konsumen dari kelompok ekonomi menengah ke bawah. Menurut data Badan Pusat Statistik DKI (terakhir tersaji tahun 2001), lapangan kegiatan ekonomi terbesar yang digeluti PKL di Jakarta adalah penjualan makanan/minuman.

Bagi konsumen yang dihadapkan pada keterbatasan pilihan atas produk (barang dan/atau jasa) yang harus dikonsumsi, kehadiran PKL dapat dipandang bermanfaat, terlepas apakah dalam perspektif yang lebih luas kehadiran tersebut mengganggu dimensi keadilan dan kepastian hukum.

Sebagai contoh, ketiadaan izin yang diberikan kepada PKL dengan sendirinya telah memperlemah spektrum pengawasan yang dapat dilakukan oleh pemerintah terhadap produk yang mereka perjual-belikan. Ketiadaan pengawasan ini jelas sangat merugikan konsumen. Laporan pengujian Badan Pengawas Obat dan Makanan (Badan POM) terhadap produk makanan/minuman yang diperdagangkan oleh PKL, beberapa waktu lalu menunjukkan cukup banyak sampel pangan (antara lain bakso, tahu, mie basah, sirup, dan cendol) yang sudah tercemar bahan-bahan berbahaya seperti formalin, borax, rhodamin B, benzoat, sakarin, dan siklamat. Hal yang memprihatinkan, misalnya, terjadi pada makanan/minuman yang menjadi jajanan anak-anak sekolah. Makanan/minuman tersebut antara lain mengandung salmonella karena diproduksi secara tidak higienis.

Menurut investigasi yang dilakukan Badan POM, sebagian besar bahan-bahan tersebut, seperti formalin, borax, dan rhodamin B, ditambahkan pada tingkat distribusi. Artinya, pada saat pedagang mengambil mie basah atau tahu dari produsen pertama, makanan-makanan tersebut mungkin saja belum diberi tambahan bahan-bahan berbahaya itu. Baru setelah makanan ini berada di tangan pedagang berikutnya, bahan-bahan berbahaya ini ditambahkan.

Penambahan bahan-bahan berbahaya ini tentu saja memiliki tujuan tertentu, yang sekali lagi sangat bersifat pragmatis. Pemakaian bahan pewarna rhodamin B, misalnya, dilakukan untuk memberi daya tarik tersendiri bagi konsumen. Es cendol yang berwarna terang, dipandang lebih mengundang selera konsumen daripada es cendol yang berwarna gelap tetapi alami. 
Pendekatan pragmatis seperti diperlihatkan oleh PKL bertolak dari dua kondisi yang samasama tidak ideal. Pertama, ada kondisi ketidakmampuan pasar untuk menyediakan bahan-bahan substitusi yang dapat dipakai oleh PKL tersebut. Bahan pewarna rhodamin B jelas lebih murah harganya dibandingkan dengan bahan pewarna makanan/minuman yang direkomendasikan aman. Ini berarti, ada kebutuhan mendesak untuk memasarkan secara luas pengganti bahan pewarna (dengan efek pewarnaan seperti diperlihatkan rhodamin B) namun bahan itu tetap aman jika ditambahkan ke dalam makanan/minuman.

Kedua, ada kondisi yang memperlihatkan rendahnya tingkat kesadaran pelaku usaha dan konsumen dalam mengkritisi fenomena penggunaan bahan-bahan berbahaya tersebut. "Histeria massa" dalam bentuk pemboikotan terhadap makanan/minuman tertentu mungkin dapat terjadi sewaktuwaktu, tetapi biasanya hal itu tidak bertahan lama dan dengan mudah dilupakan tanpa sesuatu tindakan berarti untuk mencegah hal demikian tidak berulang lagi di kemudian hari.

Dengan demikian, dari perspektif konsumen akhir, PKL adalah sesuatu yang memang sebenarnya dibutuhkan. Mereka terbukti tetap eksis karena apa yang mereka jual adalah sesuatu yang sesuai dengan kebutuhan konsumen setempat. Sebagai contoh, sekalipun di mal atau pusat perbelanjaan tersedia food court yang menjajakan segala macam hidangan, dalam kenyataaannya tetap ada sekelompok orang yang bekerja di lingkungan tersebut yang tidak termasuk kategori konsumen food court ini. Para sopir yang sedang mengantarkan majikan mereka berbelanja atau sebagian karyawan mal yang ingin berhemat, akan cenderung memilih jajanan PKL di dekat lokasi tersebut.

Tentu saja perspektif konsumen ini harus diimbangi dengan pendekatan yang lebih komprehensif. Artinya, kehadiran PKL di lokasi-lokasi seperti yang telah disebutkan tidak boleh sekadar dilihat dari perspektif perlindungan konsumen saja. Kehadiran PKL yang terus bertambah dari waktu ke waktu, atau keberadaan seorang PKL dalam jangka waktu lama di sesuatu tempat justru merepresentasikan "kegagalan" pemerintah dalam melakukan pembinaan terhadap mereka.

\section{PKL adalah juga "Konsumen"}

Dua bagian uraian sebelumnya membawa pada suatu simpulan bahwa keberadaan peraturan di tingkat daerah sesungguhnya merupakan awal yang baik untuk menata PKL di Jakarta. Pemerintah perlu menata PKL ini tidak semata-mata karena alasan estetika kota, melainkan juga karena ada kepentingan umum lain yang harus ikut diakomodasi. Kepentingan itu menyangkut masyarakat yang menjadi konsumen langsung PKL dan bukan konsumen langsung PKL tersebut.

Selain sebagai pelaku usaha yang dalam kesehariannya berhadapan dengan konsumen, PKL pun pada tataran tertentu sebenarnya juga adalah konsumen. Dalam konteks ini, yang dimaksud PKL sebagai "konsumen" adalah karena mereka merupakan subjek yang menjadi sasaran kebijakankebijakan pemerintah. Atas nama "pembinaan", pemerintah daerah mengeluarkan berbagai aturan yang harus mereka cerna dan ikuti. Para PKL ini, dengan demikian, merupakan "konsumen" dari ketentuan norma hukum positif produk penguasa.

Pembinaan terhadap PKL adalah salah satu fungsi pemerintah daerah yang tidak dapat dijalankan secara setengah hati. Ada kompleksitas permasalahan seputar PKL, yang bahkan mensyaratkan suatu pendekatan secara makro, antarsektor, dan lintas wilayah.

Jika PKL dipandang juga sebagai konsumen kebijakan pemerintah, pembinaan yang dilakukan terhadap PKL juga harus dalam perspektif pemberdayaan masyarakat. Apa yang dilakukan oleh Hernando de Soto (1991:68-108), ahli ekonomi dari Peru, dalam mencermati fenomena PKL di negaranya, kiranya berangkat dari perspektif ini. 
Sama seperti halnya di Indonesia, kondisi di Peru adalah kondisi masyarakat yang terpuruk dengan ciri-ciri mendekati praktik merkantilisme di Eropa abad ke-15 sampai dengan ke-19. Merkantilisme adalah sistem perekonomian yang ditata menurut pertimbangan politik. Akibatnya, banyak aturan yang dibuat dengan sistem birokrasi yang berbelit-belit. Akses untuk bermain di dalam pasar formal dikuasai oleh segelintir orang yang memiliki kedekatan dengan penguasa. Sebagai jalan untuk menembus sistem birokrasi tersebut, muncul sekelompok orang yang berpraktik sebagai kelompok redistribusi dan guilda. Kelompok ini dalam bahasa awam dapat disebut sebagai "broker" atau "calo". Salah satu pertanda kelahiran merkantilisme ini adalah lahirnya broker atau calo berdasi yang bermodalkan koneksi erat dengan penguasa.

Akibat dari praktik semua ini, banyak anggota masyarakat yang harus "mengonsumsi" aturan atau kebijakan yang tidak fair. Hernando de Soto sendiri melakukan eksperimen dengan mencoba mengajukan izin pendirian sebuah perusahaan kecil. Ia memutuskan untuk mengikuti semua prosedur resmi dan tidak akan menyogok, kecuali jika tanpa sogokan itu berakibat menghentikan semua proses perolehan izin. Ternyata, Hernando de Soto menemukan sepuluh kali dimintakan uang sogok. Dua di antaranya terpaksa dipenuhi. Total waktu yang dibutuhkannya adalah 285 hari. Untuk itu, Hernando harus mengeluarkan biaya "mondar-mandir" mengurus izin tersebut sebesar US\$ 1.231. Pada waktu itu (1983), uang sebesar itu sama nilainya dengan 32 kali upah minimum bulanan.

Hernando de Soto menunjukkan bahwa pelaku usaha informal (termasuk PKL) bukanlah kelompok masyarakat tanpa modal. Akan tetapi, modal tersebut menjadi tidak efektif pemanfaatannya karena harus dialamatkan pada sistem birokrasi perizinan yang tidak transparan. Akhirnya, tidak mengherankan apabila kelompok masyarakat tersebut lebih memilih berusaha tanpa izin daripada harus meminta izin namun dengan bersusah payah.

Sistem perizinan harus ditopang oleh transparansi. Dalam konteks PKL, perizinan harus terkait dengan kejelasan kriteria PKL itu sendiri, yaitu mereka yang berusaha di lokasi yang tidak sesuai dengan peruntukannya. Oleh karena PKL berusaha di lokasi yang tidak sesuai dengan peruntukannya, maka izin yang diberikan ini harus bersifat sementara. Ukuran kesementaraan yang dimaksud adalah selama yang bersangkutan belum sanggup mencari tempat yang sesuai dengan peruntukan usahanya. Dengan demikian, akan terjadi rotasi penempatan PKL yang berorientasi pada semangat pemberdayaan sebanyak mungkin kelompok usaha kecil.

Tentu saja kebijakan demikian sangat banyak mengandung celah-celah untuk disimpangkan. Indikator untuk dinyatakan "mampu pindah lokasi," misalnya, sering kali tidak mudah dilacak melalui pendekatan formal. Tidak mustahil cukup banyak PKL yang terbukti mampu membeli lahan sawah baru di kampung halamannya dengan tetap berusaha kaki lima di Jakarta. Untuk melacak kemampuan tersebut perlu keterlibatan komponen masyarakat lain sebagai mitra pemerintah. Dalam konteks ini, lagi-lagi dapat belajar dari orang lain, misalnya dari Muhammad Yunus, pemenang hadiah Nobel tahun ini atas dedikasinya memberikan bantuan permodalan bagi kaum miskin di Bangladesh melalui Grameen Bank.

Pembinaan dengan memperlakukan PKL sebagai "konsumen kebijakan pemerintah" ini pada gilirannya harus berujung pada perluasan pangsa pasar atas konsumen PKL itu sendiri. Upaya ini dapat dianggap sebagai gerakan "menaikkan kelas" para PKL dengan menyediakan lokasi khusus yang benar-benar sesuai untuk peruntukan "Pe-Ka-eL" (yang telah naik kelas) ini. Jika demikian halnya, definisi PKL menurut versi peraturan di tingkat daerah, tentunya perlu ditinjau ulang. 


\section{SIMPULAN}

Fenomena PKL tidak tampil sesederhana seperti diasumsikan di dalam produk hukum seperti halnya peraturan daerah. Untuk itu pendekatan yang lebih komprehensif menjadi keharusan di dalam penanganan masalah-masalah PKL. Kehadirannya dapat menjadi catatan tersendiri dari sudut perlindungan terhadap konsumen produk-produk mereka, namun perlindungan serupa juga perlu diberikan kepada mereka, mengingat posisi mereka adalah konsumen juga, yakni konsumen suatu kebijakan publik dari penguasa negara. Posisi keberpihakan untuk meningkatkan kualitas kehidupan mereka pada akhirnya menjadi pilihan sikap yang penting untuk dikedepankan.

\section{DAFTAR PUSTAKA}

Bromley, R. (2000). Street vending and public policy: a global review. International Journal of Sociology and Social Policy, 20(1/2), 1-28. ISSN: 0144-333X.

De Soto, H. (1991). Masih Ada Jalan Lain: Revolusi Tersembunyi di Negara Dunia Ketiga. Terjemahan Masri Maris. Jakarta: Obor Indonesia.

Harris, J. W. (1982). Law and Legal Science: An Inquiry into the Concepts Legal Rules and Legal System. Oxford: Clarendon Press.

Murray, A. J. (1994). Pedagang Jalanan dan Pelacur Jakarta: Sebuah Kajian Antropologi Sosial. Jakarta: LP3ES.

Radbruch, G. (1973). Rechtsphilosophie. Stuttgart: K.F. Koehler.

Shidarta. (2005). Penegakan Hukum dalam Perspektif Budaya Hukum. PPH Newsletter, No. 62, September, hlm. 13-15.

. (2006). Peraturan tentang Pedagang Kaki Lima dalam Sudut Pandang Kajian Filsafat Hukum dan Perlindungan Konsumen. Makalah Seminar PKL di Hotel Borobudur, Jakarta, 5 Desember 2006.

Simanjuntak, M. C. C. (2007). Preman-Preman Jakarta. Jakarta: Pensil-324.

Sudarto. (1996). Metodologi Penelitian Filsafat. Jakarta: Raja Grafindo Persada. 